\title{
Group decision making for a manufacturing organization considering intensity of preference
}

\author{
Chakraborty, P.S. ${ }^{a,}{ }^{,}$, Sarkar, B. ${ }^{b}$, Majumdar, G. ${ }^{c}$ \\ ${ }^{a}$ Adult, Continuing Education and Extension Department, Jadavpur University, Kolkata, India \\ ${ }^{\mathrm{b}}$ Production Engineering Department, Jadavpur University, Kolkata, India \\ 'Mechanical Engineering Department, Jadavpur University, Kolkata, India
}

\begin{abstract}
A B S T R A C T
To remain competitive in this global market, time to time organizations must decide about some strategic issues, future course of action and implementation strategies. Group decision making is always better than individual decisions as group talent is more than that of any individual. The main purpose of this paper is to represent a group decision making model considering the preference of individual participants. In real life, decision making processes are based on Yes-No voting system, which may not reflect the decision makers real intention. This paper deals with a case study of strategic decision making for an organization with the help of Analytic hierarchy process based group decision making model considering preference intensity of individual voters. The final decision is taken based on the ratio of benefit from particular criteria to cost and associated risk involved on that particular criterion. It is observed that this model takes care of objective as well as subjective criteria simultaneously. One possible limitation is that all the alternatives may become unsuitable in a particular case. This model is easy to apply as it is based on traditional Analytic hierarchy process method. This methodology can be used in any kind of societal selection process.
\end{abstract}

\section{ARTICLE INFO}

Keywords:

Group decision

Strategic issues

Preference intensity

Analytic hierarchy process (AHP)

*Corresponding author:

p_s_c2001@yahoo.com

(Chakraborty, P.S.)

Article history:

Received 6 May 2012

Revised 26 July 2013

Accepted 14 August 2013

(c) 2013 PEI, University of Maribor. All rights reserved.

\section{References}

[1] Saaty, T.L., Shang, J.S. (2007). Group decision-making: Head-count versus intensity of preference, Socio-Economic Planning Sciences, Vol. 41, No. 1, 22-37, doi: 10.1016/j.seps.2005.10.001.

[2] Srdjevic, B. (2007). Linking analytic hierarchy process and social choice methods to support group decision making in water management, Decision Support System, Vol. 42, No. 4, 2261-273, doi: 10.1016/j.dss.2006.08.001.

[3] Saaty, T.L. (1980). The analytic hierarchy process, McGraw-Hill, New York.

[4] Lootsma, F.A., Schuijt, H. (1997). The multiplicative AHP, SMART and ELECTRE in a common context, Journal of Multi-Criteria Decision Analysis, Vol. 6, No. 4, 185-196.

[5] Mikhalov, L. (2004). Group prioritization in the AHP by fuzzy preference programming method, Computers and Operations Research, Vol. 31, No. 2, 293-301, doi: 10.1016/S0305-0548(03)00012-1.

[6] Sarkar, B., Choudhary, J.P., Mukherjee, S.K. (2000). Selection of professionals using Analytic Hierarchy Approach, Journal of Institute of Engineers (India), Interdisciplinary Division, 16-18.

[7] Bhattacharya, A., Sarkar, B., Mukherjee, S.K. (2004). A new method for plant location selection: a holistic approach, International Journal of Industrial Engineering: Theory Application and Practice, Vol. 11, No. 4, 330-338.

[8] Chakraborty, P.S., Majumder, G., Sarkar, B. (2005). Performance evaluation of existing vendors using Analytic Hierarchy Process, Journal of Scientific and Industrial Research, Vol. 64, 648-652.

[9] Hughes, C.G. (1981). Seminar on Profit improvement / Cost reduction, by National Association of Mutual Saving Banks, USA.

[10] Azfar, O., Danninger, S. (2001). Profit sharing, employment stability and wage growth, Industrial and Labour Relations Review, Vol. 54, No. 3, 619-630. 
[11] Omer, A.M. (2007). Energy, environment and sustainable development, Renewable and Sustainable Energy Reviews, Vol. 12, 2265-2300.

[12] Pacyna, J.M., Pacyna, E.G. (2001). An assessment of global and regional emissions of trace metals to be atmosphere from anthropogenic sources worldwide, Environment Review, Vol. 9, 269-298.

[13] Aly, S., Vanicek, J., Vrana, I. (2010). Logical and decisive combining criterion for binary group decision making, Journal of Systems Integration, Vol. 1, No. 1-2, 43-53.

[14] Kugler, T., Kausel, E.E., Kocher, M.G. (2012). Are groups more rational than individuals? A review of interactive decision making in groups, Wiley Interdisciplinary Reviews: Cognitive Science, Vol. 3, No. 4, 471-482, doi: 10. 1002/wcs.1184.

[15] Mich, L., Gaio, L., Fedrizzi, M. (1993). On Fuzzy logic-based consensus in group decision, Proceedings of Fifth International IFSA World Congress, 698-700.

[16] Choudhury, A.K., Shankar, R., Tiwari, M.K. (2006). Consensus-based intelligent group decision-making model for the selection of advance technology, Decision Support Systems, Vol. 42, No. 3, 1776-1799, doi: 10.1016/j.dss. 2005.05.001.

[17] Fan, Z.P., Ma, J., Jiang, Y.P., Sun, Y.H., Ma, L. (2006). A goal programming approach to group decision making based on multiplicative preference relations and fuzzy preference relations, European Journal of Operational Research, Vol. 174, No. 1, 311-321, doi: 10.1016/j.ejor.2005.03.026.

[18] Shih, H.S., Shyur, H.J., Lee, E.S. (2007). An extension of TOPSIS for group decision making, Mathematical and Computer Modelling, Vol. 45, No. 7-9, 801-813, doi: 10.1016/j.mcm.2006.03.023.

[19] Hua, Z.S., Jiang, W., Liang, L. (2007). Adjusting inconsistency through learning in group decision making and its application to China's MBA recruiting interviews, Socio-Economic Planning Sciences, Vol. 41, No. 3, 195-207, doi: 10.1016/j.seps.2005.08.001.

[20] Wanyama, T., Far, B.H. (2007). A protocol for multi-agent negotiation in a group-choice decision making process, Journal of Network and Computer Applications, Vol. 30, No. 3, 1173-1195, doi: 10.1016/j.jnca.2006.04.009.

[21] Kraus, S. (2001). Strategic negotiations in multiagent environments, Cambridge, Massachusetts Institute of Technology Press, 17-29.

[22] Ertac, S., Gurdal, M.Y. (2012). Personality, group decision making and leadership, Research paper of KOC University Turkey, from http://home.ku.edu.tr/ sertac/Personality.pdf, accessed June 17, 2013.

[23] Gary, C., Sutter, M., (2012). Groups make better self-interested decisions, Journal of Economic Perspectives, Vol26, No. 3, 157-176, doi: 10.1257/jep.26.3.157.

[24] Jones, A., Weston, R.H., Grabot, B., Hon, B. (2013). Decision making in support of manufacturing enterprise transformation, Advances in Decision Sciences, Volume 2013, doi: 10.1155/2013/326185. 